\title{
Beethoven at Large: Reception in Literature, the Arts, Philosophy, and Politics
}

David B. Dennis

Loyola University Chicago, dennis@luc.edu

Follow this and additional works at: https://ecommons.luc.edu/history_facpubs

Part of the History Commons, and the Music Commons

\section{Recommended Citation}

Dennis, David B.. Beethoven at Large: Reception in Literature, the Arts, Philosophy, and Politics. Cambridge Companion to Beethoven, , : 292-305, 2000. Retrieved from Loyola eCommons, History: Faculty Publications and Other Works, http://dx.doi.org/10.1017/CCOL9780521580748.018

This Book Chapter is brought to you for free and open access by the Faculty Publications and Other Works by Department at Loyola eCommons. It has been accepted for inclusion in History: Faculty Publications and Other Works by an authorized administrator of Loyola eCommons. For more information, please contact ecommons@luc.edu.

\section{(c) $(\mathrm{B})($}

This work is licensed under a Creative Commons Attribution-Noncommercial-No Derivative Works 3.0 License. (c) Cambridge University Press 2000 


\title{
17 Beethoven at large: reception in literature, the arts, philosophy, and politics
}

\author{
DAVID B. DENNIS
}

Amid the enormous collection of Beethoven-inspired lyric in the Beethoven-Haus archives of Bonn stands a thick folder overflowing with poems "on single sheets," in other words never published. Hand-written or carefully typed, these verses were submitted by their authors themselves, often after visits to the Geburtshausmuseum. Such amateur but heartfelt works remind us that the majority of artistic responses to Beethoven come from men and women whose names remain unfamiliar to the world of high letters; they might reveal more about how his music and life-story move general listeners than all "expert" disputations. Above all the collection symbolizes a compulsion widely felt by persons who encounter this composer, his music, or simply memorabilia and places associated with him: Beethoven lovers tend to react to his art in active, often creative fashions, not passively. Such is the intense, ongoing influence that he and his works have on Western and even world cultures, both inside and outside musical life.

The history of Beethoven's impact on the Western music tradition, discussed in this volume by Margaret Notley and Scott Burnham, contains myriad examples of his incomparable effect on nineteenth- and twentieth-century musicians. Here we will explore how his life and music also motivate endeavors in non-musical areas, including literature, the visual arts, philosophy, politics, even religion. Beethoven has been idolized by persons of all walks of life, and many nationalities, as a "role model" or an "educator." His triumphs over deafness and loneliness fixed his reputation as a paradigm of the "artist." Inspired by this heroic image and the élan of his most popular works, musicians, writers, visual artists, politicians, and a host of others have attempted to imitate aspects of his personality, and convince others to do likewise.

That Beethoven's was a complex character partly explains the diversity of ways listeners set him into their cultural and ideological horizons. Combing through records of his inconsistent, even volatile nature, interpreters have found evidence to support associating the composer and his music with almost every modern current of thought and behavior. The goal of this chapter is not to critique the manner in which listeners under-

[292] stand Beethoven: whether it is Beethoven's "actual" person and music or 
legends about them that affect how individuals write, design, philosophize, govern, or worship is not the point. But while reviewing productive responses triggered by his music, it is important to keep in mind the difference between Beethoven the hero and "Beethoven Hero."

Early literary reactions to Beethoven included critiques of his compositions - and person - as "complicated," even "bizarre": Mozartian detractors warned that his "new style" had the potential to ignite a blaze that could consume all music rules. By the beginning of the nineteenth century, however, the mere mention of Beethoven's name aroused notions of "genius" among the avant garde of musical taste. ${ }^{2}$ Reasons for this revision of the critical framework, which transformed judgment of Beethoven as a Great Man into an "article of superstition," remain the subject of debate. ${ }^{3}$ Some propose a broad explanation linking contemporary revolutions in science, society, and politics to new ways of listening which rendered "modern" audience members more amenable to Beethoven's turbulent manipulation of musical forms. ${ }^{4}$

Within the broad strokes of this framework, a peculiar sort of individual is commonly identified as having first practiced the "modern" way of listening and provoked others to idealize above all the "rush" of Beethoven's creations. Scholars generally agree that common perceptions of Beethoven were strikingly - and permanently - colored by his young contemporaries, the Romantics. E. T. A. Hoffmann and Bettina Brentano urged listeners to interact emotionally with music, Beethoven's in particular, seeking and expressing soulful responses instead of merely being entertained. Doing so, they helped overcome initial resistance to the vigor of these compositions and launched the tradition of exploring parallels between Beethoven's works and other artistic forms of expression. ${ }^{5}$

Romantics underscored Beethoven's self-description as a Tondichter or "poet of tones" in order to associate him with their own goal of synthesizing the arts. This epithet functioned as a beacon summoning interpreters to mine his music for poetical ideas. ${ }^{6}$ Most poetic allusion to Beethoven, however, aims at revealing the secrets behind his unique creative prowess. Leading Romantics such as Clemens Brentano and Friedrich de la Motte-Fouqué pictured Beethoven as a conjurer commanding spirits from whom he received musical ideas, extending associations with magical idealism to the extreme. ${ }^{7}$ In 1813 Brentano may have been the first to suggest that his loss of hearing could be considered an advantage, comparing the deaf composer to a blind seer:

Without senses, the same as God

Knowing and writing only himself. ${ }^{8}$

Downloaded from https://www.cambridge,org/core, Loyola University of Chicago, on $08 \mathrm{Sep} 2017$ at 20:04:17, subject to the Cambridge Core terms of use, available at htps://www.cambridge.oGambridge.GompanionsiQninecosambridge.University Press, 2011 
Franz Grillparzer, who had the honor of eulogizing Beethoven at his Vienna funeral, portrayed the composer as outcast and ignored, doomed to suffer alone, but - like a fairy-tale wizard - in possession of magnificent powers:

An enchanter, tired of the world and life,

Sealed his magic in an impregnable chest,

Threw the key into the sea, and died.

Little men gave it all they had, in vain!

No tool opened the stubborn lock.

The magic slept like its master. ${ }^{9}$

In his fantastic characterization of 1831 Ernst Ortlepp portrayed Beethoven as a sorrowful Werther wandering through sublime scenes like those Caspar David Friedrich painted:

There stands a loner

In the mid of night,

On the rocky cliffs.

Beneath him thunders

The waterfall;

Beyond, the old castle

Shimmers supernaturally. ${ }^{10}$

Nikolaus Lenau's "Beethoven's Bust" (1855) countered the usual equation of Beethoven and turbulence with all-too-rare allusions to the composer's gentler side:

Shhh! Still softer!

Hear the songs

Picked up from nature's spirit,

Which it whispers

In the first dreams of a beautiful child. ${ }^{11}$

To the vital tradition of Beethoven reception in France, ${ }^{12}$ Charles Baudelaire contributed his own "evil flower." La Musique (1857), dedicated to Beethoven, carried romantic natural imagery to the very end, where Baudelaire made his usual decadent shift into pessimistic selfanalysis:

Music often takes me like a sea...

a raging storm on the great deep my cradle,

and dead calm the looking-glass of my despair! $!^{13}$

Across the Atlantic, Walt Whitman modeled verse on Beethoven's pulsing compositions: "Hasting, urging, restless, - no flagging, not even in the 'thoughts' or meditations - to be perceived with the same perception that 
enjoys music - free and luxuriant - as in Beethoven's." 14 The American bard expressed his love for Beethoven's Septet op. 20 explicitly - like "nature laughing on a hillside in sunshine" 15 - but it is in the structure of his lines, long and expansive, pressing forth themes conceived on a grand scale, that one senses the most telling indications of Beethoven's influence on Whitman's art. ${ }^{16}$ Rarer than efforts to betoken the composer's genius are such attempts to produce poetry that somehow follows the rhythms and formal developments of his music. T. S. Eliot revealed intriguing musical concepts behind his own "Four Quartets" (1942) presumably inspired by Beethoven's late works: ${ }^{17}$ "I think that a poet may gain much from the study of music ... It is in the concert room rather than in the opera house that the germ of a poem may be quickened." 18

Alongside poetic invocations of Beethovenian vitality, novels and short stories tend to address the composer in more direct ways, either through passing references in tales not otherwise focused on him or through characters modeled on his personality and life story. ${ }^{19}$ Wolfgang Robert Griepenkerl's novella Das Musikfest oder Die Beethovenianer (1841) stands out because it represents the extent to which references to Beethoven can carry narrative forth in a story which is not primarily about him. The entire work, about conflict between conservatives and "Beethovenians" over a festival intended to promote his music, was contrived to let characters voice opinions of the composer. Some attack him as mad and dangerous, others worship him as a liberalizing force somehow associated with the European revolutions of 1830. Every conversation leads to Beethoven, whether among orchestra members, salon guests, or lovers. This panoply of Beethoven allusions signifies every extreme in early reception, especially politicization of the composer by Vormärz (c. 1830-48) leftists and rightists.

Better known to English speakers are references to Beethoven in E. $M$. Forster's A Room with a View (1908) and Howard's End (1910). Both instances - when Lucy Honeychurch disturbs her friends by playing the Piano Sonata op. 111 on a rainy day in Florence ${ }^{20}$ and when Helen Schlegel listens to "the most sublime noise that has ever penetrated into the ear of man" - register the ongoing influence of Romanticism on literary allusion to Beethoven. For Forster's Helen, the last movement of the Fifth Symphony "started with a goblin walking quietly over the universe, from end to end. Others followed him ... Panic and emptiness! Panic and emptiness!... Beethoven took hold of the goblins and made them do what he wanted ... But the goblins were there. They could return. He had said so bravely, and that is why one can trust Beethoven when he says other things." 21

This image of a superhuman tamer of spirits also predominates in 
stories that depict Beethoven himself or feature characters based on him. The earliest fictionalized portraits, Johann Peter Lyser's Ludwig van Beethoven (1834), Elise Polko's Ludwig van Beethoven (1852), and Wolfgang Müller von Königswinter's Furioso (1861), highlight the composer's youth. Many elements of these portrayals - ill treatment by his father, shyness, a sense that the world does not understand him, roaming in free nature, disdain for money, and especially the desire for creative force instead of love-were standard in other novels of the period wherein Romantics fantasized about wholly fictional artists. ${ }^{22}$ Regardless of their origin, these characteristics mark bellelettristic depictions through the twentieth century. Although he never made a concrete reference to the composer in his own novels, Victor Hugo sketched the main lines of Beethoven representation: "crippled body, flying soul," producing music like a "deep mirror in a cloud" that reflects everything his listeners desire; in it "the dreamer will recognize his dream, the sailor his storm ... and the wolf his forests." 23

Important examples of characters based on the composer are Romain Rolland's Jean Christophe and Thomas Mann's Adrian Leverkühn. Writing when his countrymen were still stinging from their defeat in the Franco-Prussian War, Rolland identified Beethoven as a hero who could inspire Frenchmen to shake off their malaise. Answering Charles Péguy's call for "saints and heroes in a godless time," Rolland presented the composer as a holy martyr who sublimated pain through creative acts. ${ }^{24}$ "Blessed is the misfortune that has come upon thee! Blessed the sealing of thine ears!"25 wrote Rolland, since it was by overcoming the terror of deafness that Beethoven showed a path to self-redemption: "poor, sick, alone - and yet a victor!" 26 Rolland produced several books and essays to popularize his reading of Beethoven - indeed, to found a Beethoven cult in France, in spite (and even denial) of his hero's Germanic origins. His masterwork was Jean Christophe (1904-12), an epic about an artist whose youth was directly based on the composer's, especially in the sense of obstacles overcome. .

Thomas Mann incorporated into Doktor Faustus (1947) every sort of literary response to Beethoven: reference to specific works, direct portrayal of the composer, and association of the real with an imagined artist, Adrian Leverkühn. The best-known Beethoven components of this novelistic critique of National Socialism appear in two lectures given by the stuttering music teacher, Wendell Kretschmar. The first is an analysis of Beethoven's Piano Sonata op. 111, which Kretschmar represents as the culmination - and terminus - of sonata form. In the context of general Beethoven reception, however, the second major reference - in Kretschmar's lecture on fugue - is more important: this wartime portrait 
tied the composer to Mann's desperate assessment of German culture, in light of its crimes against humanity and humanism, as demonic:

It was in high summer of the year 1819, at the time when Beethoven was working on the Missa solemnis... He worked in his room on the Credo, the Credo with the fugue - [two visitors] heard him through the closed door. The deaf man sang, he yelled and stamped above the Credo - it was so moving and terrifying that the blood froze in their veins as they listened. But as in their great concern they were about to retreat, the door was jerked open and Beethoven stood there - in what guise? The very most frightful! With clothing disheveled, his features so distorted as to strike terror to the beholders; the eyes dazed, absent, listening all at once; he had stared at them, they got the impression that he had come out of a life-and-death struggle with all the opposing hosts of counterpoint. ${ }^{27}$

By depicting him as afflicted, Mann blended Beethoven's genius with that of his main character, Leverkühn, who was ravaged by the effects of syphilis and an imagined pact with the devil. To be sure, Mann's Beethoven stood only half way down the ladder toward dementia: Leverkühn's reactionary modernism would complete the fall and herald Germany's return to its barbaric roots. Yet, by spotlighting an anecdote of Beethoven in extremis Mann linked him to the notion that genius entails mental imbalance. Through this selective use of biographical detail, Doktor Faustus drew Beethoven into the post-Auschwitz context, marked by obsession with the satanic side of Western society and art.

As in poetry, narratives modeled on the music of Beethoven instead of just touching upon his life are less common. One novel written with a specific Beethoven work in mind is Anthony Burgess's Napoleon Symphony (1974). "What I have in front of me when I am working is the score of the Eroica. I will make the various sections of the novel correspond to the various sections of the symphony, so that if I take, say, eight bars of Beethoven, it's roughly equivalent to three pages of my own work." 28 To do this, he filled his story with the thoughts and actions of Napoleon Bonaparte, starting with two brusque pinches on the cheeks of his bride (suggesting, with much irony, Beethoven's opening $\mathrm{E} b$ chords), including battles at Rivoli, Acre, Marengo, Borodino, the Berzina River, and Waterloo, and ending with death-rattle fantasies on St. Helena. It is in repeated images, phrases, and even whole paragraphs that readers sense Burgess's "musical" form. "The novel," he declared, "is based on the life of Napoleon, but the life is so organized that it fits into a symphonic pattern, so that you don't worry too much about chronology. You worry about themes and trying to contrive an allegro movement, a scherzo, and a set of variations for a finale. In other words, following exactly ... the pattern of Beethoven's Eroica." 29 
Burgess's abstract approach notwithstanding, popularizing and explaining Beethoven are the motives behind most literary references. Nowhere is this tendency stronger than in the array of plays and films portraying Beethoven. ${ }^{30}$ Judging from the critical response to a recent theatrical portrait, Bernard Rose's film The Immortal Beloved (1994), it is the potential to suggest the personal significance of individual compositions that most fascinates dramatists and their audiences: hence the large number of plots centered on his failed loves, his struggle over nephew Karl, and his deafness - often combined with dream sequences in which the composer converses with muses about the emotional content of his works. ${ }^{31}$ Though never fully realized, and often descending into kitsch, a "total experience" of Beethoven's daily life and creative process seems their common goal.

Evocations in poems, stories, novels, and dramas afford authors and readers alike means to identify with the person they believe responsible for the pleasures and meanings they derive from Beethoven's music. However, literary treatment alone does not satisfy the impulse to relate with this composer: thus the urge to represent him in all the visual media. The ubiquitousness of Beethoven imagery in nineteenth- and twentiethcentury fine arts, and its even wider presence in commercial bric-a-brac, has had the ironic effect of making his physical appearance more familiar than his music. Beethoven portraits, illustrations, and cartoons in infinite variety have been used to promote anything remotely related to the Western music tradition (and much that is not). Thus the "sign" of this composer's mien in particular has come to "signify" serious Western music in general. However, the commercialization of Beethoven's physiognomy in the second half of the twentieth century overshadows a long tradition of fashioning his likeness for reasons other than marketing. Through every phase of modern art history, painters and sculptors have conveyed their regard for this musician as a source of inspiration across artistic boundaries. ${ }^{32}$

Portraits done during Beethoven's life, often in a Romantic vein, established a number of constants in the visual representation of this genius. Unruly hair, tensed brow, frowning mouth, gaze directed elsewhere: some of these traits have become visual clichés used to portray and imitate "modern artists" as a whole. ${ }^{33}$ After Beethoven's death, his image underwent the worst forms of Biedermeier trivialization, the most widely distributed were pictures of "Beethoven by the Brook," ostensibly composing his Sixth Symphony. ${ }^{34}$ But it was in mid-century that attempts to capture his "titanic" presence in stone, bronze, and paint began in earnest. Fulfilling Robert Schumann's call for a "Monument for Beethoven" and at 
the same time confirming his fears about how "Philistines"would manage the matter, ${ }^{35}$ cities associated with Beethoven's life commissioned statues through the century. ${ }^{36}$ Taken together, these monuments embody the conflicting motives of depicting the composer "as he really appeared" while simultaneously idealizing him: strategies include cleansing him of dermatological imperfections, restraining his hair within classical proportions, and draping toga-like garments on him. ${ }^{37}$

One of the most successful placements of Beethoven on a pedestal is Kaspar Clemens Zumbusch's Vienna monument (1880). Scowling downward, the composer is as imposing as Michelangelo's Moses (though in nineteenth-century dress). The apotheotic effect of this bronze is achieved by allegorical figures surrounding the subject: Prometheus and Nike symbolize the dichotomous nature of his creativity, nine putti play the "roles" of his symphonies, an eagle is awestruck by his presence. ${ }^{38}$ Taking this iconographical strategy to fin-de-siècle extremes, Max Klinger devoted seventeen years to gathering materials and sculpting symbols for his gesamt-representation of Beethoven-as-hero, first exhibited at the 1902 Vienna Secession. Perceiving the composer in Nietzschean terms, Klinger enthroned him on a craggy block of purple marble suggesting Zarathustra's aerie, the heights of which even eagles strain to reach. Stripped almost bare, the composer overwhelms his feathered visitor with utter concentration, jaw taut and fists clenched. Yet it is again associated imagery, on the jewel-encrusted throne, that communicates Klinger's far-reaching conception of the composer. His blend of purple, black, and white marbles; bronze, gold, and ivory; opals, agate, and jasper; classical, pagan, and Christian imagery presents Beethoven as encompassing the whole of Western tradition ${ }^{39}$ - in Nietzsche's words, one whose "gaze has become strong enough to make out the bottom of the dark well of being and . . . the distant constellations of future civilizations." 40

Likewise obsessed with Beethoven, French sculptor Antoine Bourdelle produced over forty-five versions of him in various media between 1887 and 1929.41 Bourdelle left many of his busts with rough and ragged surfaces suggesting primal forces in the composer's character: like Michelangelo's bound slaves, Bourdelle's Beethovens emerge from earth's stony veins (see Plates 1 and 2). But the most telling aspect of this artist's renderings of Beethoven's visage is their sheer number. Never convinced that he had captured the face definitely, Bourdelle returned to it again and again, each time discovering a new Beethoven, ever more distorted by his sufferings - or by the sculptor's recognition that no single perspective could signal the totality of the man.

Perhaps the most popular of Beethoven-related paintings in its own

Downloaded from https://Www. cambridge org/core. Loyola University of Chicago, on 08 Sep 2017 at 20:04:17, subject to the Cambridge Core terms of use, available at $h t t p s: / / w w w . c a m b r i d g e .0$ Gambridge. Companions1Qnine-OCambridger University Press, 2011 
time was Lionello Balestrieri's Beethoven: Kreutzer Sonata (Plate 3). Its moving romanticization of the La Boheme milieu may explain much of the acclaim this picture enjoyed at the 1900 World Exposition in Paris. ${ }^{42}$ But Balestrieri's decision to depict men and women in postures of transfixion while listening to Beethoven's sonata for violin and piano (with the composer's presence suggested only via a mask on the wall) also seems to have touched a popular chord. Liberated from the need to monumentalize the earthbound source of these experiences, images suggesting their spiritual impact may best convey the transcendentalism of Beethoven's masterworks. This is nowhere more true than in the friezes Gustav Klimt designed to complement Klinger's sculpture at the 1902 Vienna Secession exhibition. Fashioned in Klimt's suggestive style intimating psycho-sexual drives then being postulated by Sigmund Freud, each of the three panels proposes psychological correlates for portions of Beethoven's Ninth Symphony (see Plates 4-7). Implying that Beethoven struggled to avoid traps of sensual desire and sublimated libido into art, Klimt's imagery raised the ire of some who condemned the friezes as pornographic. ${ }^{43}$ It also tempted Beethoven reception into terms of sexuality that were to become central to scholarship in the second half of the century then dawning. ${ }^{44}$

Devotees who consider Beethoven's creative force in metaphysical terms have also drawn him into Western philosophical discourse. Pianist and critic Edward Dannreuther produced in 1876 a florid example of philosophizing about the composer: "The serious study of Beethoven's music is assuredly as powerful an auxiliary in the cause of culture as the study of philology. The spirit of Beethoven is as humanizing as the spirit of Sophocles. To read a string quartet, even taken in the light of a bracing intellectual exercise, seems on a par with reading a Platonic dialogue. Nay, one may affirm more than this - Beethoven is, in the best sense of the word, an ethical, a religious teacher." 45 Sure to make today's formalists wince, Dannreuther's argument is nonetheless part of an important current of reception among general listeners and major philosophers.

Hegel did not make direct reference to Beethoven, even in his extensive writings about music aesthetics. But on the basis that the composer owned a volume or two of Hegel's works, and sometimes simply because of their contemporaneity, interpreters have sought to establish that the two men ordered experience and ideas similarly. One view holds that Beethoven's inner existence progressed according to Hegelian patterns: "Beethoven's life, like Hegel's conception of reality, is a Becoming that advances only through negation and contradiction. His life was a flux, a manifestation of Hegel's Unruhe; but its goal was rest, at a point where man, having become aware of the dialectical process within him, has 


\section{Beethoven at large}

become truly free." 46 Related to this dialectical analysis of Beethoven's spiritual evolution are idealistic interpretations of his music. Granted that Haydn, Mozart, and other eighteenth-century composers contributed to the development of the "sonata principle," Beethoven's manipulation of this form earns highest standing among Hegelians: "It is he who pursues most relentlessly the dialectic of becoming, driving his thematic complexes through from what they are not but seem to be, to what they are but appear not to be." 47

Among philosophers who did discuss Beethoven and his music, Nietzsche, Theodor Adorno, and Ernst Bloch stand out. They genuinely incorporated ideas about the composer into their thought. As a young man, Nietzsche set forth in poetry the awe he felt before this sublime creator:

I look upon you mutely,

Wishing to ask your eyes,

Why, you miraculous man,

Does my pulse beat stormily

When you pass through the forest of my soul? ${ }^{48}$

The philosopher felt a strong affinity with Beethoven, recognizing that both suffered and gained from solitude: "There will always be demi-gods who can endure life and live victoriously under such terrible conditions; and if you want to hear their lonely song, listen to the music of Beethoven." ${ }^{39}$ It was only with Beethoven, in Nietzsche's view, that music "began to discover the language of pathos, of passionate desire, of the dramatic events which take place in the depths of man ... Beethoven was the first to let music speak a new language, the hither to forbidden language of passion." ${ }^{20}$ Moved by the Sternenzelt (starry canopy) depicted in the Ninth's finale, Nietzsche allowed that one could employ the symphony heuristically to apprehend the philosophy of Dionysus: "Transform Beethoven's Ode to Joy into a painting; let your imagination conceive the multitudes bowing to the dust, awestruck - then you will approach the Dionysian. Now the slave is a free man, now all the rigid, hostile barriers that necessity, caprice, or 'impudent convention' have fixed between man and man are broken." 51

Adorno advocated a musical sociology in which the "inner syntax" of musical language correlates with social conditions and cultural patterns (whether composers are conscious of this or not)..$^{52}$ After his apprenticeship in Classicism, works of Beethoven's "second style period" signaled to Adorno bourgeois-humanist hope that a "whole" man might emerge from the ruins of the ancien régime: "If we listen to Beethoven and do not hear anything of the revolutionary bourgeoisie - not the echo of its

Downloaded from httos:/www.cambridge.erg/core. Loyola University of Chicago, on 08 Sep 2017 at 20:04:17, subject to the Cambridge Core terms of use, avallable at https://www.cambridge.oGambridge. BomapanionsiQninecobambridgen.University Press, 2011 
slogans, the need to realize them, the cry for that totality in which reason and freedom are to have their warrant - we understand Beethoven no better than does one who cannot follow the purely musical content of his pieces." 53 But this optimistic moment was premature, according to Adorno: by resolving oppositions between theme (individual) and form (society) at the recapitulation of his middle works in sonata style, the composer suggested an artificial teleology just as Hegel did when he averred that the Prussian state of his time embodied the highest stage of historical evolution. To Adorno, unresolved tensions in the Missa solemnis, the late quartets, and the last sonatas better signify the outcome of the revolutionary period. Dismayed by conditions after the Congress of Vienna, Adorno's late Beethoven shed light on the true state of affairs in the post-Enlightenment world, where, detached from nature and dominated by technology, individuals would remain alienated - indeed, be rendered "inhuman." 54

Unlike Adorno and other members of the intellectual left, Bloch celebrated music not because of perceived social content, but because "it derives its energy from the anticipatory presence, from intimations of the 'not yet' ... completely beyond the scope of the empirically verifiable." 55 In very Romantic terms, Bloch described a way out of the modern impasse which he sensed in Beethoven's works especially: upon hearing them "everything false and stifling melts away. The leadenness disperses, and the distortions vanish ... 'How elated we feel at the thought of you, infinite one!'... Our soul bubbles up to the stars in the initial rough, tempestuous, eloquent sea of this music. Beethoven is Lucifer's benign offspring, the demon that leads to the ultimate things." Bloch's search for a "musical initiation into the truth of Utopia" finds "the first fully comprehensive light" in Beethoven's opera: "Every future storming of the Bastille is implicitly expressed in Fidelio ... Here and nowhere else ... music becomes a rosy dawn, militant-religious, the dawning of a new day so audible that it seems more than simply a hope."56

Though primarily philosophical, the political implications of both Adorno's analyses and Bloch's visions place them in a parallel tradition in which Beethoven and his compositions have been dogmatized and used as powerful symbols for manifold ideologies. Ludicrous as some such claims seem, politicization of Beethoven is not a matter of simple projection. He was a political man in many senses: by the end of his life he talked about politics to such an extent that some friends no longer wanted to dine with him, either because they were tired of hearing his outbursts or afraid he would be overheard by secret agents. ${ }^{57}$ However, lacking a systematically worked-out ideology in an era of shifting alliances, the

Downloaded from https:/www.cambridge,org/core. Loyola University of Chicago, on 08 Sep 2017 at 20:04:17, subject to the Cambridge Core terms of use, available at https://www.cambridge. ogambridge. Gopapanions10nine:OCambridger University Press, 2011 
composer expressed contradictory opinions at various points in his life that could be used by almost every European political movement. Politicizing Beethoven has not always required projecting doctrine onto his works, but often merely selecting indications that he would have associated with one group or another, then arguing that these stand for "our" Beethoven and that other aspects of his biography are irrelevant or misleading. ${ }^{58}$

This process has occurred across the modern political spectrum - particularly but not exclusively in Germany - and includes efforts to demonstrate that Beethoven was everything from a proto-communist to a forerunner of fascism. Romantic interpretations of the composer as revolutionary emerged by the time of the uprisings in 1848-49. After 1870 supporters of German empire endorsed aggressively nationalistic assessments while Marxists portrayed him in socialistic terms. This conflict came to a head in the first decade of the twentieth century, when the workers' movement competed against volkish critics to claim Beethoven's legacy, while liberals assigned it to elite culture. During the First World War, Germans resisted enemy assertions that they had "forfeited the right" to enjoy his music. Every political group active in the Weimar Republic "fought tooth and nail to demonstrate that he belonged exclusively to their circle." 59 Nazis imposed an image of Beethoven as an aesthetic Führer, volkish and militaristic, though small pockets of "resistance" perceived his music as a symbol of humanitarian ideals. After the Second World War, German reception mirrored the division of the nation: notions of the composer as social revolutionary reigned in East Germany while commercialization and a de-ideologizing view of Beethoven as "all-too-human" operated in the popular culture of the West. ${ }^{60}$

Political responses that highlight the aggressive aspects of his character and music - overlooking the more tranquil qualities of both ${ }^{61}$ - have been countered by voices beatifying the composer. Over the last two centuries, secularization of European society has been accompanied by a counter tendency to sanctify the arts, especially music. Romantics rejected the relegation of instrumental expression to minor aesthetic rank during the Enlightenment, affording music a sacred function by which man might transcend the quotidian and approach the infinite. ${ }^{62}$ Beethoven's art was a focal point in this world view. Bettina Brentano glorified it in an 1810 letter to Goethe: "I believe in a divine magic that is an element of spiritual nature; and this magic, Beethoven exercises in his art. All he could tell you about is pure magic; no motive, no orientation is not the expression of a superior existence." 63

For some, Beethoven becomes even more than a purveyor of sacred 
messages, himself a deity. "A second time Jesus, with his pains, ascended Calvary," exclaimed Georges Pioch at the start of the twentieth century: "A musician, it is true; but a prophet as well; I am tempted to say - a Messiah. For his work is and will be the most immeasurable of all gospels." ${ }^{64}$ In this cult of personality, Beethoven's manuscripts serve as holy texts; above all, the Ninth Symphony captivates moderns in search of secure precepts in a world of shifting mores. ${ }^{65}$ Karl Rafael Henning discovered in 1888 a set of Beethovenian commandments, each put forth in a movement of the Ninth:

I. Man's life should be a noble struggle for Virtì, despite all the powers of fate. II, Man can with discretion enjoy the delights of life but not become too caught up with them. III. Man should be submissive even before the loss of whatever love he finds on earth. IV. Above the stars lives a loving father who calls us his children and who wants us all to reach out the hand of reconciliation to one another in brotherly love. This is the greatest happiness. ${ }^{66}$

It is at this level of reverence that the startling popularity of Beethoven's Ninth Symphony in Japan seems to function. Since the Second World War it has become tradition to perform the Daiku (Big Ninth) every December throughout the country. Most remarkable about this rite is that when the choral finale arrives all sing along, audience and performers alike. The annual concert at Osaka in 1989 featured a chorus of ten thousand; sports stadiums are regularly filled for these rituals. ${ }^{67}$ The zenith of this custom occurred during the Opening Ceremonies of the 1998 Winter Olympics in Nagano, Japan. Led by conductor Seiji Ozawa, professional singers and inhabitants of local logging towns performed the Ninth Symphony in a ritual which did bring the world community together. Fin-de-millennium communications technology enabled choirs in major cities around the globe to simultaneously add their voices to this celebration of the Olympic and Beethovenian spirits. This Western composer's life and music have clearly become touchstones in world culture.

Reception history studies the ways musical ideas interact with human experience and aspiration: via interpretations and reinterpretations by listeners. Most important is that this dialectic takes place mainly after the composer's work is done, as compositions are performed through time and people engage with them more closely. It is worthwhile to consider the meanings that Beethoven and his works obtain once performed, for it is these that impact mentalities and societies, inspiring men and women to craft poems, write novels, sculpt monuments, paint friezes, order concepts, make political decisions, go into battle, worship, and embrace. What might Beethoven himself have thought about all this? Perhaps 


\section{Nietzsche's estimate is best:}

He would probably be silent for a long while, uncertain whether he should raise his hand to curse or bless, but perhaps say at last: "Well, well! That is neither I nor not-I, but a third thing - it seems to me, too, something right, if not just the right thing. But you must know yourselves what to do, since in any case it is you who have to listen. As our Schiller says, 'The living man is right.' So have it your own way, and let me go down again."68 